\title{
Obstructive Ureterocele
}

National Cancer Institute

\section{Source}

National Cancer Institute. Obstructive Ureterocele. NCI Thesaurus. Code C123238.

A ureterocele with a small, obstructive orifice. 